\title{
Fitz-Hugh-Curtis syndrome
}

\author{
Kiyoshi Shikino, Masatomi Ikusaka
}

Department of General Medicine, Chiba University Hospital, Chiba, Japan

\section{Correspondence to}

Dr Kiyoshi Shikino,

kshikino@gmail.com

Accepted 1 February 2019

\section{DESCRIPTION}

A 29-year-old woman presented with 2 days of right upper abdominal pain. The pain worsened with deep breathing and body movements, which radiated to the right shoulder. Physical examination revealed tenderness on palpation of the right upper abdomen and tenderness to percussion of the lower ribs. Endocervical culture revealed Chlamydia trachomatis. Abdominal contrast-enhanced CT showed conspicuous increased perihepatic enhancement on the right lobe of the liver (figures 1 and 2). Fitz-Hugh-Curtis syndrome was diagnosed, which improved after azithromycin was administered.

Fitz-Hugh-Curtis syndrome is considered a rare complication of pelvic inflammatory disease, mostly associated with C. trachomatis. The right upper abdominal pain appears as the main symptom and becomes more severe in response to deep breathing and body movements. Occasionally, the pain may radiate to the right shoulder. The increased enhancement along the hepatic surface on CT has been described as a finding that can suggest the diagnosis of Fitz-Hugh-Curtis syndrome. ${ }^{1}$

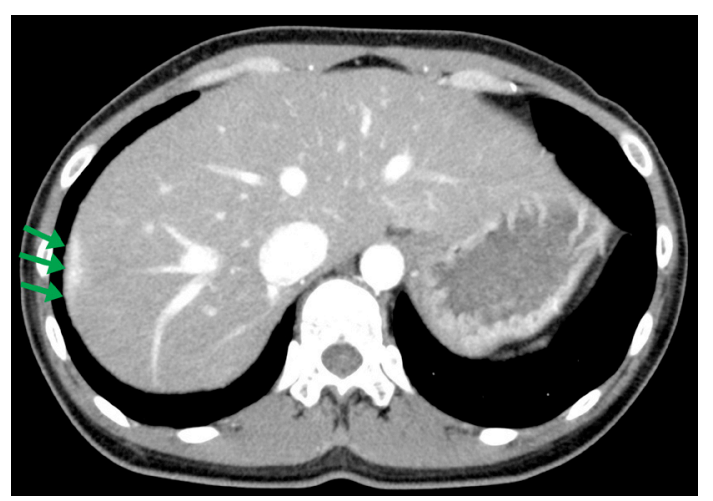

Figure 1 Contrast-enhanced CT (axial) showed conspicuous increased perihepatic enhancement on the right lobe of the liver (arrows).

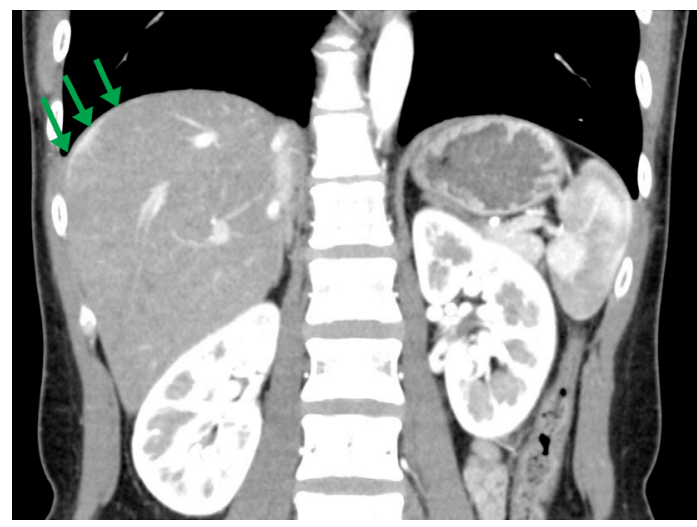

Figure 2 Contrast-enhanced CT (coronal) showed conspicuous increased perihepatic enhancement on the right lobe of the liver (arrows).

\section{Learning points}

- Fitz-Hugh-Curtis syndrome present right upper abdominal pain worsened with deep breathing and body movements.

- The increased enhancement along the hepatic surface on $\mathrm{CT}$ is a characteristic finding of FitzHugh-Curtis syndrome.

Contributors KS managed patient. KS wrote the draft. MI revised this article.

Funding The authors have not declared a specific grant for this research from any funding agency in the public, commercial or not-for-profit sectors.

Competing interests None declared.

Patient consent for publication Not required.

Provenance and peer review Not commissioned; externally peer reviewed.

\section{REFERENCE}

1 Nishie A, Yoshimitsu K, Irie H, et al. Fitz-Hugh-Curtis syndrome. radiologic manifestation. J Comput Assist Tomogr 2003;27:786-91.

Copyright 2019 BMJ Publishing Group. All rights reserved. For permission to reuse any of this content visit

https://www.bmj.com/company/products-services/rights-and-licensing/permissions/

BMJ Case Report Fellows may re-use this article for personal use and teaching without any further permission.

Become a Fellow of BMJ Case Reports today and you can:

- Submit as many cases as you like

- Enjoy fast sympathetic peer review and rapid publication of accepted articles

- Access all the published articles

- Re-use any of the published material for personal use and teaching without further permission

For information on Institutional Fellowships contact consortiasales@bmjgroup.com

Visit casereports.bmj.com for more articles like this and to become a Fellow 